\title{
Future Prospects of Duck Production in Asia
}

\author{
Chein Tai ${ }^{1}$ and Jui-Jane Liu Tai ${ }^{2}$
}

1. Institute of Biotechnology, National Cheng Kung University, Tainan, 701, Taiwan, R.O.C.

2. Department of Animal Physiology, Taiwan Livestock Research Institute, Council of Agriculture, Tainan, 712, Taiwan, R.O.C.

\section{Abstract}

Asia accounted for $87 \%$ of the world's duck population in 1999. In last two decades, duck meat and duck egg production has increased more than 4 times in Asia. This increment came from the growing duck population of local breeds, as well as the expansion of imported breeds from foreign breeding companies. Future aspects of duck production in Asia will be discussed in this paper. These include the improvement of production efficiency, the influence from joint venture, the utilization of locally available feedstuffs, duck-cum-rice and duckcum-fish integrated systems, genetic resource conservation, low-fat duck production, the development of value-added duck products, product biosecurity and disease control, and pollution control of duck-raising.

\section{Introduction}

Duck production is important for many Asian countries. Asia had a duck population of 720 millions in 1999, which constituted $87 \%$ of world duck population. The world duck population has increased continuously in the past twenty years. Most of the increase was from Asian countries. In last two decades, Asian duck meat production has increased 4.3 times and, mostly from the increment of China. Asia produced 2.0 million mt of duck meat annually from 1997 to 1999, which was $80 \%$ of the world production (Fig. $1 \&$ Table 1). The trade information of duck meat indicates most ducks dressed were produced in Asia. Duck meat is mainly consumed by Chinese communities. Hong Kong, Japan and South Korea are duck meat importers in Asia. About $40 \%$ of duck meat imports goes to these three countries. Singapore, on the other hand, is the biggest importer of live ducks for processing need. It is about 30 million USD per year, mainly from Malaysia. The major production countries of duck meat in Asia are listed in Table 2. China produces $82 \%$ of the duck meat in Asia. Although chicken meat is still the major source of poultry meat in Asian countries, in some regions, such as Vietnam and China, duck meat 
also holds a significant percentage of poultry meat, $24 \%$ and $16 \%$, respectively. In China, Thailand, Malaysia, Vietnam and Japan, after recovering from the economic crisis, $f$, duck meat consumption has revived. Meanwhile, the investments of large breeding companies in Asian countries, such as Cherry Valley from UK and Grimaud Freres from France, as well as the integration with local enterprises, have significantly expanded the production within a short period. Among the major duck production countries in Asia, Taiwan is the only region, which has exhibited a decrease in duck population. The domestic consumption has not been reducing, but the exports have suffered a recession as a result of competition of lower wage and cheaper land resource in other exporting countries. The agricultural policy and awareness of environmental protection keep Taiwan from increasing duck population in the near future.

Duck egg is also an essential protein source in some Asian countries. Table 3 lists egg production excluding hen eggs in Asia. Since most of the eggs besides hen egg are produced by ducks, it is regarded as a good indication of duck egg production. Asian egg production excluding hen eggs has increased 4.4 times in last two decades. In India, Indonesia, and Philippines, ducks are mainly kept for egg production and not for meat supply.

Stimpson (1998) has described the future development of the duck industry in Asia. In here, the general information of major duck raising countries in Asia are summarized in Table 4. Both exotic breeds and local breeds are used for duck meat production. In China, Pekin duck is the major breed for meat production. However, the number of Muscovy duck is increasing in many provinces of China due to its preferable meat quality. Muscovy drakes are also used as the sire line in the production of mule ducklings. The intergeneric hybrid of Muscovy drake and common duck, mule, has been the major meat duck breed in Taiwan for many years. Local farmers routinely applied artificial inseminations to obtain the hybrids. Recently, Taiwanese businessmen are investing in duck production in Chinese coastal provinces of Taiwan Strait, and mule duck production is expanding in this area. The situation of Malaysia is similar. A French breeding company, Grimaud Freres, produces mule ducks for the market of Chinese in Malaysia and Singapore. This mule duck production trend is also noticeable in Thailand. It will be discussed later.

Another special feature of Asian duck production is the change of duck raising systems. The nomadic system is a special way to raise ducks in Asia. It is considered as a traditional method of keeping ducks. Ducks are allowed to herd on the rice fields after harvesting, or allowed to scavenge in the paddy field during certain period of rice growing cycle. Either mobile or home base type of herding system has been 
practiced in most Asian countries for centuries. Although semi-intensive and intensive duck raising systems have been developing, most Asian countries still keep this traditional method to raise ducks. In some area with prosperous industry, traditional duck production has gradually vanished. In Taiwan, duck production along the riverside or nomadic rice-duck systems is no more existing. It resulted from the competition of land resources with other industries, as well as the high wages of labors. Nevertheless, an interesting development might reconfirm the wisdom of our ancestors, which is the fact that recently Japanese has started to apply the scavenging system of ducks in sustainable agriculture (Manda, 1996). The emphasis on sustainable agriculture advocates the integrated duck-rice system by the scavenging of aigamo ducks on rice field to produce organic rice. This trend may evoke the utilization of ducks for biological control in agricultural production, leading to an increase in the consumption of duck meat and/or duck eggs.

In general, duck production in Southeast Asia is still showing vigorous progress, not only along with the growing population in Asia, but also with the potential consumption by the Chinese communities, especially because Chinese economy is expected to be better off in the new millennium.

\section{Future prospects of duck production in Asia}

Some perspectives of duck production in Asia, which are worth noting in the development of duck industry, will be described in the following sections.

\section{The improvement of efficiency in duck production}

Under the influence of imported breeds, the intensification of duck production seems to be the trend in some Asian countries. Notwithstanding, traditional systems of extensive or semi-intensive duck production are still widespread in Asia due to the integration of rice-cum-duck or duck-cum-fish production. No matter what raising system is applied, efficiency is the key element to making profit. The primary points are different for various production systems, but the efficiency can always be promoted through the genetic and technical improvements as well as the automation of management. Economic performances and fitness of ducks are substantial criteria for genetic improvement. The choice among imported breeds, indigenous breeds, or crossbreds depends on the raising system in use, as well as the objective of production. Meanwhile, some technical advance for ducks under intensive feeding system such as complete-pellet feeds, or the improvement of artificial insemination for cross breeding 
will certainly raise the efficiency of production (Tai, 1986). The supplement of local feedstuffs, especially in the duck-cum-rice or duck-cum-fish integrated system, could increase the efficiency of traditional duck-raising significantly (Setioko et al., 1994). Another advancement of production skill, which is essential to efficiency, is the automation of management. The experience from broiler growing provides us a good model for the automation in intensive production. This at least can partially explain the increment in duck production under the same production cost through the years in France (Prin, 1999). For those countries applying the intensive systems, the promotion of efficiency is a determining factor in the competition with exporting markets.

\section{Influences from the joint venture of world's leading duck companies}

In last two decades, some leading companies of duck breeding, such as Cherry Valley, Tegal, Maple leaf and Grimaud, have extended their breeding stocks to Asian countries. They have also cooperated with local firms and form industrial complex to produce ducklings within Asian countries. The French breeding company of Muscovy duck, Grimaud Freres, has set up the production system of mule ducks at Kuala Lumpur of Malaysia, by crossing Muscovy males with Pekin females artificially. Grimaud produces three million mule ducks annually for the market of Malaysia and Singapore (Anonymous, 1999). Another example is the Henan Sino-British Poultry Liability Corporation in China. It is an export-oriented enterprise specialized in Pekin duck breeding, hatching, dressing, frozen and cooked food processing, feed production, eider down processing and packing products, and medicine production. Its annul production is 500 million ducks (Anonymous, 2000). Although some exotic breeds are not always accepted by local farmers due to the different market requirement or disease problems (Ramakrishnan, 1996), these investments usually evoke a tremendous expansion of duck industry in Asian countries, and consequently, it brings huge impact on local duck production system. Under the pressure from integration among related enterprises, local farmers find it is more and more difficult to compete with the joint venture by small-scale duck production. This phenomenon indicates the crisis of losing genetic diversity in duck resources. The adaptability of local breeds to the hardy environment, which includes the ability to use local feeds and disease resistance, is precious not only to Asia but also to the whole world. Therefore, it is necessary for Asian countries to evaluate the importance of traditional duck production before introducing international duck enterprise. Some policy or strategy that suit the local circumstances may be essential in order to protecting the domestic duck industry. These international companies would contribute to the preservation of genetic resources of Asian duck breeds if they can participate in the 
selection and application of local breeds besides the extension of commercial breeds. Furthermore, these international enterprises may extend their integrated network to help local farmers by improving production technology and setting up marketing channels.

\section{Utilization of locally available feedstuffs}

Most Asian countries are feed ingredient importers, even those who used to export these grains. However, this region has non-conventional raw materials and by products, such as rice bran, copra meal, peanut meal, palm kernel, canola meal, animal offal etc, in abundance. Since ducks are hardy to local environment and have good resistance to disease, how to integrate those local feedstuffs into duck production is an urgent topic for developing countries. In a trial to improve the living standard of poor people in the villages of Vietnam, Dong et al., (1997) concluded that by efficiently using the local feed resources for Muscovy duck production, the farmers could get a good profit. Another studies on the herding of laying duck also indicated that Khaki Campbell ducks reared on locally available feedstuffs had normal egg productivity (Nho and Tieu, 1997). These facts show that Asian countries should try to make good use of local feed resources through nutrition studies of these raw materials as well as the utility by ducks.

\section{The application of duck-cum-rice and duck-cum-fish integrated systems}

Duck-cum-rice system is a traditional way to grow laying ducks and meat ducks in Asian countries (Petherham and Thahar, 1983; Farrell, 1997; Setioko, 1997). After long-term integration with rice growing season and farming scales, the traditional duck-cum-rice raising systems are different among Asian countries. No matter what type of duck-cum-rice system is adopted, the contribution of duck-cum-rice system on the rural economy is important. Moreover, this traditional system is a symbiotic relationship between rice farming and duck raising, and both groups benefit. Its flexibility on the scale of duck production benefits small producers in the countryside. However, this system is declining in Asia as a result from the development of cultivation technology, application of herbicides and pesticides, and the change of labor input structure of farms. It vanished completely in Taiwan in last two decades when the production cost and efficiency were considered solely by the farmers. Still, it is not always more profitable when confinement system was compared with semitraditional production system (Sabrani et. al., 1986). Before replacing this system with semi-intensive or intensive system, the developing countries of Asia might reevaluate the function of biological control of rice pests provided by scavenging ducks (Manda, 1992). Farrell (1997) pointed out that it was necessary to help small producer 
in setting up a more intensive, sustainable and profitable system of raising ducks but it should be less reliant on the rice farmers. The global trends in the pursuit of sustainable agriculture give Asian countries a chance to reconsider the wisdom of our ancestors. It is imperative to develop systems integrated with the local needs of duck products, farming scale and available feed resources in Asian countries.

Another integrated system of duck raising is the duck-cum-fish integration system. It has been practiced for many years in Asian countries (Edwards, 1986). It can be found in the extensive, semi-intensive or intensive duck raising farms. Fish can utilize duck excreta and feed waste directly or indirectly. Therefore, this system increases the productivity of duck-cum -fish farm, makes efficient usage of water, spreads the economic risk of price fluctuation, and most importantly, environmental impacts are minimal. On the other hand, duck-cum-fish system needs more knowledge and management, because the operation of one subsystem will affect the other subsystem significantly. Little and Sataporanvanit (1997) discussed the factors affecting the use of poultry wastes in fish culture. The duck-raising system, type of duck, poultry ration, supplement of feeds to ducks or fishes and farm management system will all influence the productivity of duck-cum-fish integration system. When intensive duck raising is inevitable in some countries, the duck-cum-fish system may provide one of the best sustainable agricultural systems to produce animal protein economically.

\section{Genetic resource conservation or prevention of genetic erosion}

As mentioned, Asia keeps $87 \%$ of ducks of the whole world, with a tremendous variety of duck breeds, such as Shaoxing, Jingdin, Shanma, Liancheng, Bai and Gaoyou duck in China (Ma and Zhao, 1998), Tsaiya in Taiwan, Alabio and Tegal duck in Indonesia, Itik Jawa in Malaysia, and Desi in India and Bangladesh. However, the abundant genetic diversity of ducks in Asia is under the pressure of uniformity of the duck breeds. Most recent trends in the production of duck in Asian countries seems to stress on higher performance in egg and meat production, keeping pure breeds such as Cherry Valley, Khaki Campbell, Pekin and Muscovy. This development definitely will endanger the population of indigenous breeds. Just like Fujihara and Xi (1999) pointed out in their paper, we have to remember that genetic diversity is needed by any species in order to maintain reproductive vitality, resistance to disease, and the ability to adapt to changing conditions in the world. Asian people have the obligation to carefully preserve the gift of nature, these indigenous breeds of ducks, which are well adapted to the hardy environment of Asia without any complicated system of management. The fitness of Asian ducks to their environment is the results of natural selection for centuries. Before replacing them with "improved 
breeds," we ought to think about the irreversible loss of genetic diversity.

Recent studies on the primordial germ cells of poultry provide an alternative way to preserve the genome of poultry besides the cryopreservation of drake spermatozoa. The technique for producing germ line chimera may be applied in preserving stock endangered under natural condition (Tajima et. al., 1993)

\section{The production of low-fat duck meat}

The requirement of low fat meat is a global trend for most consumers. The lean meat selection on Pekin ducks (Wilson et. al., 1997) or Muscovy (Baeza et. al., 1997) has been conducted. Another direction of lean meat production is to produce mule ducks. The low fat content of mule duck carcass has been reported by some researchers (Abdelsamie and Farrell, 1986; Szasz et. al., 1997; Retailleau, 1999). The 3-way cross scheme for the production of mule ducks has been practiced in Taiwan for many years (Tai, 1986). The mule ducks produced in Taiwan were consumed domestically and were also for exporting purpose in last two decades. Grimaud of France cross Muscovy drakes with Pekin ducks to produce 2-way hybrids mule ducks in Malaysia to supply the Chinese market in Malaysia and Singapore. It shows a great potential in Asian market. In addition, the sexual dimorphism of mule ducks is not significant; the body weight of mule duck is not affected by sex (Tai and Rouvier, 1998). Moreover, mule ducks can be used in the production of foie gras by forcefeeding (Salichon et. al., 1994), and breast muscle after force-feeding is a delicacy in French cuisine. With these advantages, mule duck has great potential in providing the duck meat in the whole world

The key technology to the success of mule duck production is artificial insemination, which has been applied by the mule duck farmers in Taiwan for many years (Huang and Chow, 1974). There can be a big difference in fertility among different operators; therefore, Grimaud in Malaysia records the fertility of artificial insemination achieved by individual inseminators and pays a bonus for good fertility. This technology has been exchanged with French researchers (Rouvier et. al., 1984) and it was also transferred to many Southeast Asia countries through Food \& Fertilizer Technology Center (Tai and Tai, 1991). Although the production of mule ducks in Taiwan has been partially replaced by Muscovy in recent years, the artificial insemination technology applied in Taiwan will certainly be useful in any countries, which are going to produce mule ducks for meat purpose.

\section{The development of value-added duck products}

Many special duck products are consumed in Asian countries. These products include processed duck meat, such as roasting Pekin duck, pressed salt duck, 
ginger-root duck, smoked duck steak and duck roll, tea-smoked duck, herb duck, crispy skin duck, etc., and processed duck eggs, such as salted duck eggs, thousandyear duck eggs, and balut, which is popular in Philippines and Vietnam. It is a fertile egg incubated for 17-18 days then boiled and served with salt.

Besides meat and eggs, parts of the viscera is also processed as a famous appetizer, such as salted duck gizzards and marinated duck tongues. In Taiwan, specialized shops for duck meat processing are prevalent. Although housewives still buy the whole duck from market to prepare dishes sometimes, the trends go toward buying processed products. Variety is important to increase the consumption of duck meat. Vacuum packagings of oven-ready duck meat or frozen pre-cooked ducks are welcome to housewives. Those processed products, not only prolong the time of storage, but also contribute significantly to the value of ducks. Famous roasting Pekin duck creates a business from the tourists visiting the Great Wall in China. More business is awaiting if duck producers can produce more value-added duck products to supply the requirement of local market or exporting market.

Duck down feather processing is another important by-product of ducks. With high quality processing technology, Taiwan exported USD 130 million worth of down feather products annually. The countries which produce meat ducks might develop the down feather processing plants and get good profit from this valuable by-product.

\section{Product biosecurity and disease control}

The requirement for food safety by consumers is becoming an issue in all countries of the world. The contamination by Salmonella in duck production is serious and common due to the improper management. The production conditions of many Asian producers are below the standards of biosecurity. Thus producer needs to address this problem by developing improved methods of production (White et. al., 1997; Stimpson, 1998).

Effective disease control by vaccination in duck production is another vital point to the progressive development of duck industry in Asia. Important diseases of waterfowl have been described by Sandhu (1999). Although some diseases like duck virus enteritis can be protected by vaccination, some are not, such as Avian Influenza. The information on duck disease is far from complete and needs to be established both for intensive system or traditional system. More studies are needed in developing rapid diagnosis, low-cost vaccine, and efficient methodology in the administration of vaccines.

\section{Less pollution from duck-raising}

The increasing density of duck rearing and the awakening of environmental 
protection hinder the traditional duck raising along the riverside in some Asian countries. Especially those countries with limited land area will require a system to treat duck wastewater before disposal. It is also one of the bottlenecks in the development of intensive duck industry. The wire-floor or slotted-floor housing of ducks provides a possible way to control the disposal of wastewater. The 3-step treatment system developed by the Duck Research Center of Taiwan (Koh, et al., 1999) has been tried in the removal of pollution from laying ducks in cage or slottedfloor duck houses. This is accomplished by pre-treating duck excreta with a solidliquid separator, followed by fermentation in an anaerobic sludge reactor and then in an aerobic sludge reactor.

As aforementioned, integrated duck-cum -fish production system has been well practiced for many years in some areas of Asia. Although the role of integrated system of duck-cum-fish has never been set on the reduction of pollution, the potential of earthen fish ponds to treat sewage and waste water is well recognized (Edwards, 1993). Fishponds play an important role in closing the nutrient cycle and alleviate eutrophication in an agroecosystem (Varadi, 1995). One hectare of static water fishponds can "process" the wastes of up to 1500 poultry, producing fish in quantities of up to $10 \mathrm{mt} / \mathrm{ha}$ without other feeds or fertilizers (Little and Sataporanvanit, 1997). Therefore, this duck-cum-fish model could also provide an alternative choice for sustainable system of duck farming.

\section{Acknowledgement}

Many thanks are given to Dr. N, Fujihara and Dr. M. Furuse for their kind invitation of me to this Symposium. I would also like to express my sincere gratitude to Dr. A.R. Setioko, Dr.de Guzuman, Mr. H.B. Yoke, Dr. M.C. Chung, Mr. J. C. Chen, and Mr. C. M. Lee for providing the information for this article. We also extend our deepest appreciation to Dr. Po Chung of COA for editing this manuscript.

\section{References}

Abdelsamie, R. E., and D. J. Farrell. 1986. Carcass composition and carcass characteristics of ducks. pp. 83-101. In :Duck Production Science and World Practice. (Eds. Farrell, D. J. and Stapleton, P. S.) University of New England, Armidale, NSW.

Anonymous, 1999. French breeder's Asian success. International Hatchery Practice, June, 7-11.

Anonymous, 2000. Sino British Poultry Group. Poultry International. March, 2000, 
p.34.

Baeza, E., H. de Carville, M. R. Salichon, G. Marche, B. Leclercq, 1997. Effects of selection, over three and four generations, on meat yield and fatness in Muscovy ducks. British Poultry Science, 38:359-365.

Dong N.T.K., B. Ogle, and T. R. Preston. 1997. Effect of level of local supplements for fattening Muscovy ducks by poor farmers in remote villages in Mekong delta of Vietnam. The Electronic Journal. Livestock Research for Rural Development, Vol 9 No. 1

Edwards, P. 1986. Duck/fish integrated farming systems. In: Duck Production Science and World Practice, pp 267-291. (Eds. Farrell, D. J. and Stapleton, P. S.) University of New England, Armidale, NSW.

Edwards, P. 1993. Environmental issues in integrated agriculture-aquaculture and wastewater-fed fish culture systems. In: Environment and aquaculture in developing countries. pp. 139-170. (Eds. Pullin, R.S.V., Rosenthal H. and Maclean J.L.), ICLARM Conf., Proc. 31.

Farrell, D. J. 1997. Integrated wetlands rice and duck production systems in humid tropics of Asia: current and future trends. Proceedings of $11^{\text {th }}$ European Symposium on Waterfowl, Nantes (France). 483-489.

Fujihara, N., and Y. M. Xi. 1999. Genetic resource conservation in the waterfowl. Proceedings $1^{\text {st }}$ world Waterfowl Conference, Taiwan, ROC. pp.63-69.

Huang H. H. and T. C. Chow. 1974. Artificial insemination in mule duck production. Proceedings XV World Poultry Congress. New-Orleans, Washington, USA. pp.261-262.

Koh, M. T., F. K. Kuo, and S. C. Huang. 1999. The study on duck wastewater treatment. J. Chin. Soc. Anim. Sci., 28(1):69-80.

Little, D. and K. Sataporanvanit. 1997. Poultry and fish production- a framework for their integration in Asia. Paper No. 28. Proceedings Second FAO Electronic Conference on Tropical Feeds Livestock Feed Resources with Integrated Farming Systems.

Ma, C. and Q. Zhao, 1998. China's waterfowl production takes off. World poultry, 14(4):40-41.

Manda, M. 1992. Paddy rice cultivation using crossbred ducks. Agricultural Science and Nature Resources, Faculty of Agriculture, Kagoshima University. Farming Japan 26(4):35-42.

Manda, M. 1996. Aigamo (crossbred duck)-rice farming in Asia. Farming Japan, 30:39-43.

Nho, L. T., and H. V. Tieu. 1997. Egg production and economic efficiency of Khaki Campbell ducks reared on locally available feedstuffs in the coastal land stretch 
of the Red River Delta. The Electronic Journal. Livestock Research for Rural Development, Vol 9 No. 1

Petheram, R. J., and A. Thahar. 1983. Duck production systems in West Java. Agricultural Systems 10:75-86.

Prin, S., 1999. Canard: accroissement des densites, in Enquete ITAVI sur ievolution des couts de production en 1997. Filieres Avicoles No.607:106.

Ramakrishnan, A.1996. Duck production scenario in India-scope for improvement. Proceedings XX World Poultry Congress, New Delhi, India. 3:589-596.

Retailleau, R. 1999. Comparison of the growth and body composition of 3 types of ducks: Pekin, Muscovy and Mule. Proceedings $1^{\text {st }}$ World Waterfowl Conference, Taiwan, R.O. C. pp.597-602.

Rouvier, R., J. J. L. Tai., and C. Tai.1984. L'insemination artificielle des canes communes pour la production de mulard a Taiwan, La situation actuelle. In: Insemination artifielle et amelioration genetique: bilan et perspectives critiques. Les Colloques de I'NRA no 29, 360-367.

Sabrani, M., A. Muljadi, and U. Kusnadi, 1986. Socio-economic aspects pf village duck production in central Java and Yogyakarta. pp.333-340. In: Duck Production Science and World Practice. (Eds. Farrell, D. J. and Stapleton, P. S.) University of New England, Armidale, NSW.

Salichon, M. R., G. Guy., D. Rousselot-Pailley., and J. C. Blum. 1994. Composition des 3 types de foie gras: oie, canard mulard et canard de Barbarie. Ann. Zootech.,43:213-220.

Sandhu, T. S. 1999. Diseases of waterfowl. Proceedings of $1^{\text {st }}$ World Waterfowl Conference. Taiwan, R.O.C. pp. 38-49.

Setioko, A. R. 1997. Recent study on traditional system of duck layer flock management in Indonesia. Proceedings of $11^{\text {th }}$ European Symposium on Waterfowl, Nantes (France). 491-498.

Setioko, A. R. A. P. Sinurat, P. Setiaadi, and A. Lasmini. 1994. Feed supplementation for herded ducks in Subang, West Java. Majalah Ilmu dan Peternakan 8(1): 27 33.

Stimpson, M. J. 1998. Future developments of the duck industry in Asia Pacific. World Poultry, 14:38-40.

Szasz, S., F. Bogenfurst, and I. Kobulej. 1997. Study on thigh fat content in Pekin, Muscovy and Mule ducks. Proceedings $11^{\text {th }}$ European Symposium on Waterfowl, Nates (France), pp.655-660.

Tai, C. 1986. Duck production in Taiwan. In :Duck Production Science and World. pp. 364-371. (Eds. Farrell, D. J. and Stapleton, P. S.) University of New England, Armidale, NSW. 
Tai, C. and R. Rouvier. 1998. Crossbreeding effect on sexual dimorphism of body weight in intergeneric hybrids obtained between Muscovy and Pekin duck. Genet. Sel. Evol., 30:163-170.

Tai, J. J. L., and C. Tai. 1991. Mule duck production in Taiwan. I. Artificial insemination of ducks. Food \& Fertilizer Technology Center, extension bulletin No. 328: 1-6.

Tajima, A., M. Naito, Y. Yasuda, and T. Kuwana. 1993. Production of germ line chimera by transfer of primordial germ cells in the domestic chicken (Gallus domesticus). Theriogenology, 40:509-519.

Varadi, L. 1995. Ecological aspects in integrated duck and fish production. Proceedings $10^{\text {th }}$ European Symposium on Waterfowl. Halle, Germany. Pp.8-19. White, P.L., A. R. Baker, and W. O. James. 1997. Strategies to control Salmonella and Campylobacter in raw poultry products. Rev. Sci. Tech. 16(2):525-541.

Wilson, B. J., D. M. Martin, and H. Nott. 1997. Future genetic improvements in Pekin-type ducks. Proceedings $11^{\text {th }}$ European Symposium on Waterfowl, Nates (France), pp.328-335. 
Table 1. World duck meat production and trade information (Average of 1997 to 1999)

\begin{tabular}{|c|c|c|c|c|c|c|c|}
\hline & & $\begin{array}{c}\text { Duck meat } \\
\text { production } \\
(\mathrm{mt})\end{array}$ & $\begin{array}{c}\begin{array}{c}\text { Dressed } \\
\text { ducks } \\
(\times 1000)\end{array} \\
\end{array}$ & $\begin{array}{c}\text { Exported } \\
\text { ducks } \\
(\$ 1000)\end{array}$ & $\begin{array}{c}\text { Imported } \\
\text { ducks } \\
(\$ 1000) \\
\end{array}$ & $\begin{array}{c}\text { Exported } \\
\text { duck meat } \\
(\$ 1000)\end{array}$ & $\begin{array}{c}\text { Imported } \\
\text { duck meat } \\
(\$ 1000)\end{array}$ \\
\hline World & & $2,545,038$ & $1,754,191$ & 38,356 & 50,799 & 257,440 & 270,677 \\
\hline Asia & & $\begin{array}{c}2,028,189 \\
(79.7)^{*}\end{array}$ & $\begin{array}{c}1,526,254 \\
(81.0)\end{array}$ & $\begin{array}{c}28,633 \\
(74.7)\end{array}$ & $\begin{array}{l}40,782 \\
(80.3)\end{array}$ & $\begin{array}{l}88,091 \\
(34.2) \\
\end{array}$ & $\begin{array}{c}123,096 \\
(45.5) \\
\end{array}$ \\
\hline \multirow{5}{*}{$\begin{array}{l}\text { Five top } \\
\text { countries of } \\
\text { world's } \\
\text { production }\end{array}$} & 1 & $\begin{array}{l}\text { China } \\
(64.9) \\
\end{array}$ & $\begin{array}{l}\text { China } \\
(72.4) \\
\end{array}$ & $\begin{array}{c}\text { Malaysia } \\
(47.5)\end{array}$ & $\begin{array}{c}\text { Singapore } \\
(59.1) \\
\end{array}$ & $\begin{array}{l}\text { France } \\
(26.5)\end{array}$ & $\begin{array}{c}\text { Germany } \\
(28.3)\end{array}$ \\
\hline & 2 & $\begin{array}{c}\text { France } \\
(8.3)\end{array}$ & $\begin{array}{c}\text { France } \\
(4.6)\end{array}$ & $\begin{array}{l}\text { China } \\
(20.6) \\
\end{array}$ & $\begin{array}{c}\text { Hong Kong } \\
(11.3)\end{array}$ & $\begin{array}{l}\text { China } \\
(10.5)\end{array}$ & $\begin{array}{c}\text { Hong Kong } \\
(18.5)\end{array}$ \\
\hline & 3 & $\begin{array}{l}\text { Thailand } \\
(4.3)\end{array}$ & $\begin{array}{c}\text { Thailand } \\
\text { (4.1) }\end{array}$ & $\begin{array}{l}\text { Canada } \\
(12.0)\end{array}$ & $\begin{array}{c}\text { France } \\
(6.3)\end{array}$ & $\begin{array}{l}\text { Netherlands } \\
(10.0)\end{array}$ & $\begin{array}{l}\text { Japan } \\
(17.3)\end{array}$ \\
\hline & 4 & $\begin{array}{c}\text { Taiwan } \\
(2.6)\end{array}$ & $\begin{array}{c}\text { Vietnam } \\
(2.8)\end{array}$ & $\begin{array}{c}\text { France } \\
(5.5)\end{array}$ & $\begin{array}{c}\text { Malaysia } \\
\text { (3.5) }\end{array}$ & $\begin{array}{l}\text { U.K. } \\
(9.2)\end{array}$ & $\begin{array}{c}\text { Korea Rep. } \\
(5.0)\end{array}$ \\
\hline & 5 & $\begin{array}{c}\text { Vietnam } \\
\text { (2.3) }\end{array}$ & $\begin{array}{c}\text { Taiwan } \\
(2.1)\end{array}$ & $\begin{array}{l}\text { India } \\
(3.8)\end{array}$ & $\begin{array}{c}\text { Macao } \\
(2.8)\end{array}$ & $\begin{array}{c}\text { Brunei } \\
(7.5)\end{array}$ & $\begin{array}{l}\text { U.K. } \\
(3.4)\end{array}$ \\
\hline
\end{tabular}

*Data in the parenthesis are the percentage in world's production.

\section{From: FAOSTAT}

Table 2. Major duck meat production countries in Asia and their average production from 1997 to 1999.

\begin{tabular}{lccccc}
\hline Country & $\begin{array}{c}\text { Ducks (stock) } \\
(\mathrm{x} \mathrm{1000)}\end{array}$ & $\begin{array}{c}\text { Duck meat } \\
\text { production } \\
(\mathrm{mt})\end{array}$ & $\begin{array}{c}\text { \% of Asian } \\
\text { production in } \\
\text { duck meat }\end{array}$ & $\begin{array}{c}\text { Poultry meat } \\
\text { production } \\
(\mathrm{mt})\end{array}$ & $\begin{array}{c}\text { \% of } \\
\text { poultry } \\
\text { meat }\end{array}$ \\
\hline China & 562,000 & $1,653,000$ & 81.5 & $10,379,670$ & 15.9 \\
\hline Thailand & 21,276 & 108,510 & 5.4 & $1,145,685$ & 9.5 \\
\hline Taiwan & 12,118 & 65,606 & 3.2 & 740,790 & 8.9 \\
\hline Vietnam & 49,533 & 59,680 & 2.9 & 251,282 & 23.8 \\
\hline Malaysia & 13,000 & 49,833 & 2.5 & 780,833 & 6.4 \\
\hline \multicolumn{1}{c}{ Total } & 657,927 & $1,936,629$ & 95.5 & $13,298,260$ & Ave. 14.6 \\
\hline
\end{tabular}

From: FAOSTAT

Table 3. Major production countries of duck eggs in Asia and their average production from 1997 to 1999*

\begin{tabular}{lccrrc}
\hline Country & $\begin{array}{c}\text { Laying stocks } \\
\text { (x 1000) }\end{array}$ & $\begin{array}{c}\text { Egg excluding } \\
\text { hen ( mt) }\end{array}$ & $\begin{array}{c}\text { \% of Asian } \\
\text { production }\end{array}$ & $\begin{array}{c}\text { Primary egg } \\
\text { production } \\
\text { ( } \mathrm{mt})\end{array}$ & $\begin{array}{c}\text { \% of Primary } \\
\text { egg production }\end{array}$ \\
\hline China & - & $3,976,000$ & 87.3 & $20,079,330$ & 19.8 \\
\hline Thailand & 18,333 & 273,333 & 6.0 & 780,062 & 35.0 \\
\hline Indonesia & 21,633 & 144,085 & 3.2 & 614,884 & 23.4 \\
\hline Philippines & 10,766 & 64,666 & 1.4 & 589,000 & 11.0 \\
\hline Taiwan & 2,913 & 30,393 & 0.7 & 387,393 & 7.8 \\
\hline Total & & $4,488,477$ & 98.6 & $22,450,669$ & Ave. 19.4 \\
\hline
\end{tabular}

From :FAOSTAT

*India has a duck population of 23 million mainly for egg purpose, and it is $8.53 \%$ of total poultry 
Table 4 General information of duck production in major duck-raising countries of Asia.

\begin{tabular}{|c|c|c|c|c|c|}
\hline \multirow[t]{2}{*}{ Country } & \multirow[t]{2}{*}{ Major products } & \multirow[t]{2}{*}{$\begin{array}{l}\text { Major breed } \\
\text { resource }\end{array}$} & \multicolumn{2}{|c|}{$\begin{array}{c}\text { Increment of } \\
\text { production in last two } \\
\text { decades }\end{array}$} & \multirow[t]{2}{*}{ Future trends } \\
\hline & & & meat & egg & \\
\hline China & Meat \& eggs & $\begin{array}{l}\text { Local, Pekin, } \\
\text { Muscovy, } \\
\text { mule }\end{array}$ & $\begin{array}{c}\uparrow 7 \mathrm{x}^{*} \\
1,454,000 \\
\mathrm{mt}\end{array}$ & $\begin{array}{c}\uparrow 7.3 x \\
3,540,000 \\
\mathrm{mt}\end{array}$ & $\begin{array}{l}\text { Growing, Muscovy and } \\
\text { mule duck population } \\
\text { increase, exportation is } \\
\text { increasing }\end{array}$ \\
\hline Thailand & Meat \& eggs & $\begin{array}{l}\text { Local, Pekin, } \\
\text { mule }\end{array}$ & $\begin{array}{c}\uparrow 1.6 \mathrm{x} \\
38,030 \mathrm{Mt}\end{array}$ & $\begin{array}{c}\text { No } \\
\text { increase }\end{array}$ & $\begin{array}{l}\text { Growing in meat } \\
\text { production by big } \\
\text { enterprise, exportation } \\
\text { is increasing }\end{array}$ \\
\hline Taiwan & Meat \& eggs & $\begin{array}{l}\text { Local, mule } \\
\text { Muscovy, } \\
\text { Pekin }\end{array}$ & $\begin{array}{c}\uparrow 1.3 x \\
14,096 \\
\mathrm{mt}\end{array}$ & $\begin{array}{c}\uparrow 1.1 \mathrm{x} \\
1,639 \mathrm{mt}\end{array}$ & $\begin{array}{lll}\text { Exportation } & \text { and duck } \\
\text { population } & \text { are both } \\
\text { decreasing } & & \end{array}$ \\
\hline Vietnam & Meat \& eggs & Local, Pekin & $\begin{array}{c}\uparrow 1.7 \mathrm{x} \\
24,240 \mathrm{mt}\end{array}$ & $\begin{array}{c}\text { Not } \\
\text { available }\end{array}$ & $\begin{array}{l}\text { Local breeds is } \\
\text { decreasing, but total } \\
\text { production is growing }\end{array}$ \\
\hline Malaysia & Meat \& eggs & Local, & $\begin{array}{l}\uparrow 1.4 \mathrm{x} \\
29,100\end{array}$ & $\begin{array}{c}\uparrow 3 \mathrm{x} \\
9,200 \mathrm{mt}\end{array}$ & $\begin{array}{lr}\text { Foreign } & \text { leading } \\
\text { company } & \text { investment }\end{array}$ \\
\hline & & & $\mathrm{mt}$ & & $\begin{array}{l}\text { for exporting mule } \\
\text { ducks }\end{array}$ \\
\hline Indonesia & Eggs & Local & $\begin{array}{c}\text { No } \\
\text { increase }\end{array}$ & $\begin{array}{c}\uparrow 2 \mathrm{x} \\
72,600 \mathrm{Mt}\end{array}$ & $\begin{array}{l}\text { Improving duck-rice } \\
\text { integration system }\end{array}$ \\
\hline
\end{tabular}

* $\uparrow:$ Increase in production, the ratio of production derived from $1999 / 1980$, and total increment (mt).

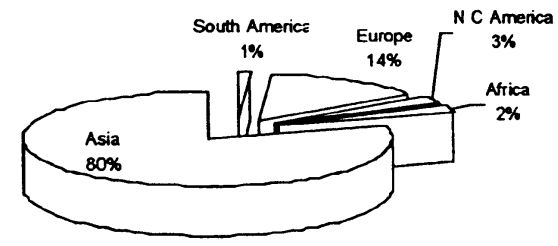

Fig.1 Duck meat production of the work 